\title{
Winter Meeting, 1995
}

The Winter Meeting was held at the Moat House International Hotel, Glasgow on 31 January to 3 February 1995.

\section{Business Meeting}

The business meeting was held on 1 February 1995 attended by 34 members of the College.

\section{Minutes}

The minutes of the 1994 winter business meeting held on 3 February 1994 at the Café Royal, London were approved and signed.

\section{Election of Honorary Fellows}

The following were nominated and seconded:

HRH The Duchess of Kent, Dr A. Coppen, Professor C. Pierce, Professor G. Russell and Dr R. Sadoun.

\section{Registrar's Report}

During the second half of 1994 the College continued to be much exercised by the output of the Department of Health. Discussions were continuing about the Supervision Register when the Draft Guide to Interagency working was published and broadly welcomed by the College.

Public Policy Committee has been negotiating with the Benefits Agency to improve the mental illness assessment for incapacity benefit. This has been a very successful exercise resulting in real changes to threshold for benefit and to procedures for assessment, and I would like to thank $\mathrm{Dr}$ Laurence Measey for his detailed work on this subject.

Two new subcommittees of the Public Policy Committee have met. The Mental Health Law Group has accepted the challenge put down by Professor Elaine Murphy and Sir Louis BlomCooper and will be commencing a review of the principles of the Mental Health Act in advance of the expected review in a few years time. The group has also considered the criteria for Section 12 approval - on which discussions will be taking place with the Department of Health and the proposed Supervised Discharge Orders.

Ensuring that Parliament understands the clinical views on Supervised Discharge Orders is now the responsibility of the Parliamentary Liaison Committee which is setting up mechanism by which College Members can meet and discuss aspects of mental health with MPs and Peers. They will be aided in their work by the re-establishment of the All Party Parliamentary Mental Health Group, for which the College is providing secretarial assistance this year. Mrs Cameron was re-elected by the Group as Honorary Secretary.

There was a highly successful Conference on Community Care in October coinciding with Mental Health Week and the College's Community Care Policy is about to be published, having been endorsed by Council on Monday.

The Clinical Guideline Development Programme has also now commenced activity following the appointment of a Facilitator whose first task is to obtain from College Members and others, a list of priority areas in which guidelines are needed. The methodology for this process has been agreed and is contained in a Council Report.

A proposal was put by the Executive and Finance Committee to Council on the restructuring of College Sections. This is currently undergoing consultation with Chairmen of Sections, and will be discussed again at the March Council.

The ECT Working Party has updated its guidelines on ECT practice and these were endorsed by Council on Monday.

The Continuing Professional Development Office is progressing in setting up the necessary system for accrediting courses and certificating doctors.

Two new special interest groups have their inaugural meetings tomorrow - Biological and Perinatal Psychiatry.

Two further special interest groups on eating disorders and women and psychiatry have been agreed by Council and are awaiting the required 50 signatures.

The College continues in discussions with the Chief Medical Officer about the Certificate of Completion of Specialist Training and 
implementation of the Calman Report. Further details should be available before the Annual Meeting.

We continue to take very seriously the training and appointment of College Assessors to sit on Advisory Appointment Committees in view of the great pressure to appoint consultants in areas of skill shortage. In view of recent adverse publicity for the Royal Colleges in Hospital Doctor, I am pleased to be able to report that this College has an active training day for assessors including training on aspects of racial and gender equality with a contribution from the Commission for Racial Equality.

Finally President, I would like to say how much those of us from England appreciate the opportunity to visit Glasgow for this meeting in spite of the inclement weather-it's no different elsewhere in the UK. It is encouraging to see that, in spite of the reaffirmation of sensible drinking units by Council, our Scots colleagues can still stretch out Burns Night for a whole week - by my calculations, the real Burns Night was last Wednesday!
Anyway it is a particular pleasure to be here so soon after the opening of the office of the Scottish Division, situated in the RCP Edinburgh, a development which we are sure will be an advantage to Scottish psychiatry, especially in its relations with the Scottish Office.

Finally, the Irish Office is also now open for business.

Professor CHRIS THOMPSON, Registrar

\section{Matters arising}

The question was raised as to the problems that arise from the timing of the Winter Meeting and the fact that it coincides with the rotation of many psychiatric training posts. The President informed the meeting that this had been noted but that unfortunately, due to the need to book venues some years in advance, this could not have been altered for 1995 but would be for 1996. 